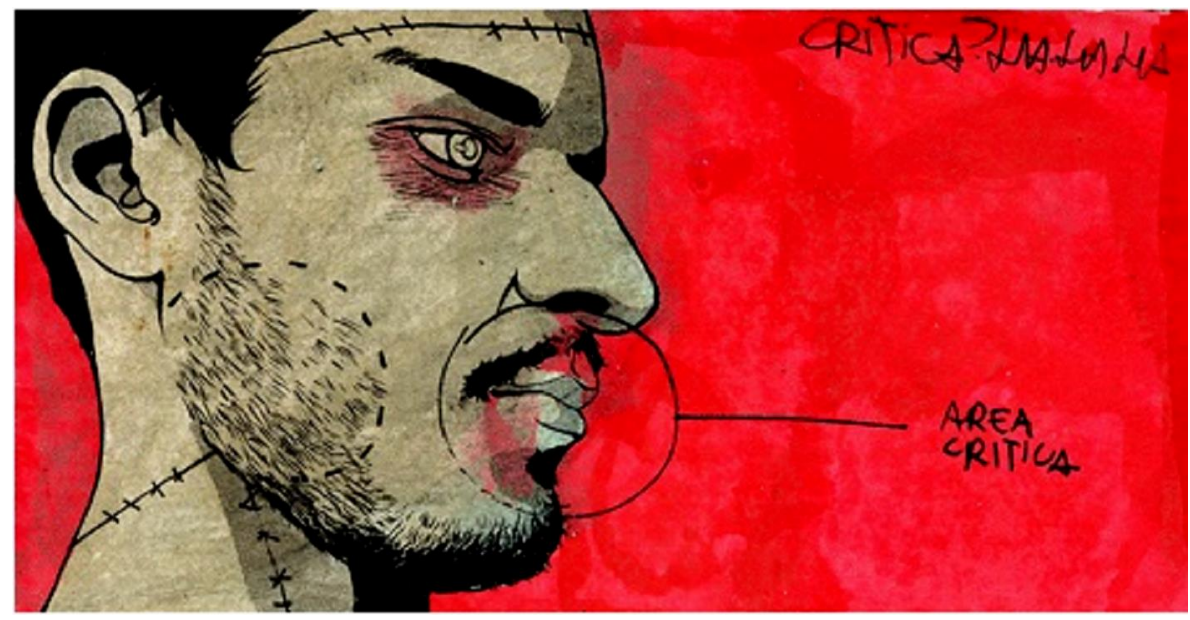

Joao Paulo Tiago

\title{
A arte das estratégias narrativas e a qualificação do leitor: uma breve análise a partir de Adorno
}

\section{Marcelo Chiaretto}

Doutor em Estudos Literários pela UFMG com Pós-Doutorado em Literatura e Educação pela PUC-Rio, é professor de Língua Portuguesa, Literatura Brasileira, Redação e Teoria Literária, atuando no Ensino Médio do Colégio Técnico, na Faculdade de Letras e na Faculdade de Educação da Universidade Federal de Minas Gerais, sendo membro pesquisador do programa de Ensino, Pesquisa e Extensão A Tela e o Texto e do Grupo de Pesquisa do Letramento literário - GPELL/CEALE/FAE.

\section{Resumo}

Como ter acesso a uma "arte" sem transformar e modificar a própria sensibilidade? Como conhecer uma "arte" sem encontrar a realidade das alteridades? Este artigo pretende analisar processos artísticos direcionados às áreas de cinema e literatura e as respectivas estratégias narrativas, considerando-se as possibilidades de se firmarem elaborações aptas a qualificar e educar o público receptor. A teoria em uso abrange estudos estéticos de Adorno, Hegel, Walter Benjamin e Roland Barthes.

Palavras-chave: literatura, cinema, recepção. 
A arte é a promessa de felicidade que se quebra. Adorno

Não seria novidade afirmar que toda atividade artística, incluindo-se aí a ação audiovisual cinematográfica ou fílmica e a ação literária, tem como principal pressuposto o impulso por corresponder à necessidade humana de absorver, transformar e modificar a realidade, transmitindo idéias e emoções. A rigor, pode-se inferir que o cinema e a literatura preocupados com a qualificação do receptor determinam para si mesmos a necessidade de um leitor (ou espectador) inquieto, ágil, ativo - em suma, desperto -, tendo em vista a fundamentalidade de sua participação, ou melhor, da sua co-produção no processo de criação literária ou cinematográfica.

Com efeito, há, no cinema atual, certa ênfase hollywoodiana na espetacularização da força contra a complexidade do debate político, ao mesmo tempo em que se vê, no campo literário, uma larga produção editorial de livros de auto-ajuda ou temas sensacionalistas, datados em sua busca pelo entretenimento fácil e ansiosos por dar ao preguiçoso leitor receitas de bem viver. No entanto, percebe-se, em determinada produção artística, a explícita ênfase na competência da recepção, o que, se a valoriza, por um lado, também revela, por outro, certo eruditismo, muitas vezes superficial e inócuo.

Diante disso, é necessário verificar que tal característica elitista, presente em obras que buscam confrontar o gosto acomodado dos leitores, como todo processo que versa sobre a exigência de uma maior criticidade da população, acaba por exigir maior criticidade da população, o que pode impor a certas obras uma restrição pública. Afirma-se uma leitura não assegurada, obviamente, para todos os leitores e que pode, eventualmente, gerar aversão à sociedade ou ao Estado.

\section{A negatividade}

Adorno, um dos teóricos da Escola de Frankfurt, foi um dos grandes defensores de processos que pudessem valorizar a recepção das obras de arte. Para ele, "a ininteligibilidade que se censura nas obras de arte herméticas é o reconhecimento do caráter enigmático de toda a arte"(1). Essa afirmação implica redefinir o valor da negatividade expressional, um recurso que, segundo o filósofo, seria primordial para garantir o mistério e a ambigüidade, traços que, do seu ponto de vista, estariam aptos a consolidar a inesgotabilidade fundamental de toda arte e, por consegüinte, de toda leitura. 
Hegel - outro teórico interessado na conformação das recepções artísticas, dentre outros aspectos - havia criticado o procedimento da negatividade expressional, por "intentar a favor da morte e da dissolução do processo artístico", ao reduzir as obras a uma existência "vazia e caprichosa", cuja decifração dependia de um leitor capaz de mergulhar na "inexpugnável e total interioridade de um autor", retratado como "vaidoso e egocêntrico"(2). Hegel reivindicava a legibilidade, a necessidade de uma recepção tranqüila, um conteúdo com "um caráter verdadeiro" e com "finalidades essenciais", capaz de proporcionar um "meio para fins morais"(3). Enquanto "picardia contra o público", segundo ele, os recursos que colocavam como primordial a valorização do receptor manifestariam, então, teimosia em relação à originalidade e incompetência, ao serem incapazes de expressar o "sentimento e o espírito da nação alemã e de seu tempo"(4).

Tais críticas foram realizadas por Hegel como uma forma de se contrapor à teoria romântica sobre a negatividade na arte concepções formuladas pelos alemães F. Schlegel e Novalis. Após considerável espaço de tempo, Adorno estabelece uma espécie de resposta a essas críticas. Com efeito, nunca chegou a haver uma "resposta" por parte dos próprios teóricos românticos, uma vez que, no momento das críticas hegelianas, Schlegel, por exemplo, já não estava interessado em teorizar sobre a negatividade e Novalis, por outro lado, já havia morrido. Interessado na conexão materialista possível de ser depreendida da idéia de negatividade expressional - além da perspectiva dialética e política - Adorno, dessa maneira, buscou valorizá-la por seu próprio aparato erudito e elitista, porém original e atento à qualificação do público leitor.

A recusa de sentido definitivo e a ênfase no material da arte e nas limitações desse material - e aqui se inicia uma possível explicação da citada conexão materialista - , somados ao descompromisso com o Geist (o imaginário popular, ponto de referência para a criação artística, segundo Hegel), observados então na teoria romântica relacionada ao valor da negatividade expressional na arte, seriam fundamentais, conforme Adorno, para que fossem logrados dois objetivos.

Em primeiro lugar, ao enfatizar o seu material - entendendo-se como "material" as características ou procedimentos específicos de composição - fundando-se mais apresentativa do que representativa, a obra de arte, aqui concebida na forma literária ou cinematográfica, exigiria de seus receptores uma atenção crítica e reflexiva, tornando difícil a perspectiva do prazer, ou melhor, do entretenimento. É imperioso apontar que Adorno referia esse prazer como um reflexo da perversão burguesa, ou seja, uma espécie de anomalia da classe média: 
Quem saboreia concretamente as obras de arte é um filisteu; expressões como 'delicioso para o ouvido' bastam para o convencer. [...] Na realidade, quanto mais se compreendem as obras de arte, tanto menos se saboreiam. É incontestável, como afirmam os burgueses, que ninguém se votaria à arte se dela nada retirasse. No entanto, semelhante estupidez erigiu-se em bom senso. O burguês deseja que a arte seja voluptuosa e a vida ascética; o contrário seria melhor(5).

Observa-se, nas palavras de Adorno, uma escala inversamente proporcional: quanto mais prazer, menos reflexão. Na perspectiva "burguesa" firmada na idéia da voluptuosidade na arte, as obras estavam próximas de se tornarem mercadorias sem valor simbólico, tão distantes da realidade quanto alienadoras. Segundo Adorno, quem desaparece na leitura de um livro ou na recepção de um filme é dispensado da miséria de uma vida, o que indicaria como melhor posicionamento para o receptor o distanciamento, através do qual alcançaria uma visão desmitificadora da arte e desveladora da realidade social, tendo em vista a ruptura da ilusão. Nesse momento, pode-se avistar o leitor elitista já mencionado adentrando a sociedade e seus problemas. Chega-se assim ao segundo objetivo.

Em segundo lugar, ainda conforme as concepções de Adorno, a experiência estética torna-se cada vez mais genuína à medida que se priva do entretenimento ou do prazer estético(6). Essa privação poderia afirmar uma nova postura diante da arte: em oposição à idéia de mergulhar na tela e no texto, aceitando o dito pelo dito e, dessa forma, alienando-se dos interesses do poder social, político e econômico, o receptor poderia se distanciar da narrativa, ao descobrir o não-dito sobre o dito (ou o dito como implicação do não-dito), permitindo à arte a realização de sua única função possível dentro de uma sociedade desigual e desumanizada, qual seja, a de informar e introduzir os seres no conhecimento. Em uma palavra, educar.

Para Adorno, quanto mais a obra é autônoma - "não-coisificada ou entorpecida"(7) e, sim, livre de obrigações referentes à legibilidade e ao prazer -, mais aumenta o poder do sujeito na leitura(8). De fato, vê-se uma afronta ao mercado consumidor, embora $O$ bem comum e a democracia saiam fortalecidos. Reconhecendo-se a cultura incluída na indústria do consumo, a arte - auto-consciente, mergulhada na negatividade expressional - surgiria como único elemento capaz de problematizar o processo mercantil, pois estaria apta a expor ao público o seu eloqüente e enigmático mutismo, protestando a favor de uma decifração reflexiva, crítica, transformadora da realidade.

Em contato com essa arte, o leitor sentado em um banco de praça e o espectador estirado em uma poltrona de sala de 
cinema poderiam ser capazes de conhecer a estrutura fundante das obras de arte e compreender a elaboração estética do autor. O contato com essa arte determinaria, ao mesmo tempo, a ação do leitor não-ingênuo, aquele consciente de sua função no processo que possibilita a sobrevivência da arte numa sociedade que a despreza. Para Adorno, a única mimesispermitida à arte moderna é a mimesis do que está petrificado e alienado(9), ou seja, daquilo que perdeu sua identidade. Segundo ele:

\begin{abstract}
menos do que imitar a natureza, as obras de arte traduzem a sua transposição em elementos da realidade. Em última análise, deveria derrubar-se a doutrina da imitação; num sentido sublimado, a realidade deve imitar as obras de arte (10).
\end{abstract}

\title{
Direitos fundamentais
}

Por mais utópica que pareça, a proposta de Adorno revelaria um impulso de enfocar na arte o seu efeito desconstrucionista, ao apresentá-la como apta não apenas a expressar a sua materialidade, mas também a "traduzir a sua transposição em elementos da realidade". Pode-se concluir daí que a "verdadeira" obra de arte é aquela capaz de ativar múltiplas reflexões sobre a forma com que se explica enquanto transposição de elementos da realidade ou enquanto produto de uma busca (incessante) pela referencialização. Com efeito, é essa transposição que funda a mimesis. A realidade, portanto, deveria tomar a arte como exemplo, algo tentado e muitas vezes realizado por artistas atemporais tais como são, no cinema, Jean-Luc Godard, Woody Allen, Ingmar Bergman, Fellini, Lars Von Trier, Serghei Eisenstein, e na literatura, Mallarmé, Goethe, Machado de Assis, Guimarães Rosa, Fernando Pessoa.

É interessante lembrar que Walter Benjamin também se preocupou em estudar o papel da negatividade no conceito de crítica de arte do Romantismo alemão. Seu enfoque sociológico, contudo, não é similar ao de Adorno. O teor marxista fica bem destacado em ambos os casos, ao se considerarem as constantes afirmações favoráveis à arte que procura educar o receptor ou, em outras palavras, que busca determinar-lhe uma postura radical e crítica, dando especial atenção ao seu papel social e político na construção de uma sociedade que se firma na defesa do bem público.

Neste momento, o leitor ou o espectador, antes afastado, por ser elitista ou erudito, percebe a complexidade de sua situação, ao se encontrar como ser produtivo e consumidor, na medida em que tem responsabilidades sociais, políticas e civis - ou seja, sua realidade é de uma multiplicidade indivisível. Pode-se deduzir, dessa maneira, que é um direito humano a possibilidade de exaltar a melhor forma de fazer política: optar pela relatividade ao conhecer as artes. 


\section{Abstract}

How to have access to an art object without transforming and modifying one's own sensibility? How to know an art object without finding the reality of the other? This article intends to analyze artistic processes in cinema and literature and the respective narrative strategies. This article will also take into consideration the possibilities of critical elaborations to qualify and to educate the general public. The theories to be used include aesthetic studies by Adorno, Hegel, Walter Benjamin and Roland Barthes.

Key words: literature, cinema, reception.

\section{Notas}

[1] ADORNO, $1980, \mathrm{p} .143$.

[2] HEGEL, 1992, p. 14-15.

[3] Ibidem, p. 14-15.

[4] Ibidem, p. 15.

[5] ADORNO, 1980, p. 24-25.

[6] É importante acrescentar: o que Adorno chama de "prazer", Roland Barthes, por exemplo, chama de "deleite" (jouissance), isto é, o prazer estético negativo. Cf. JAUSS, 1979, p. 73.

[7] ADORNO, 1980, p. 33

[8] Ibidem, p. 26.

[9] Ibidem, p. 33.

[10] Ibidem, p. 153.

\section{Bibliografia}

ADORNO, Theodor W. Teoria estética. Lisboa: Edições 70, 1980.

ARIStóteles. Poética. Tradução de Eudoro de Souza. São Paulo: Nova Cultural, 1991 .

BARTHES, Roland. O grau zero da escritura. Tradução de Antonio Gonçalves. Lisboa: Edições 70, 1977. $70,1974$.

O prazer do texto. Tradução de Margarida Barahona. Lisboa: Edições

BÉGUIN, Albert. L'âme romantique et le rêve. Paris: Librairie Jose Corti, 1946.

BENJAMIN, Walter. O conceito de crítica de arte no romantismo alemão. Tradução de Marcio Seligmann-Silva. São Paulo: Iluminuras, 1993.

HEGEL, G.W.F. Estética - a idéia e o ideal. Tradução de Orlando Vitorino. São Paulo: Abril Cultural, 1974. 
Txt: Leituras Transdisciplinares de Telas e Textos, Belo Horizonte, v.4, n.7, p.66-72, 2008

HEGEL, G.W.F. Esthétique - textes choisis. Tradução de Claude Khodoss. 12. ed. Paris: Presses Universitaires de France, 1992.

JAUSS, Hans Robert et al. A literatura e o leitor - textos de estética da recepção. Coordenação e tradução de Luiz Costa Lima. Rio de Janeiro: Paz e Terra, 1979 .

NOVALIS. Pólen. Tradução de Rubens R. Torres Filho. São Paulo: Iluminuras, 1988 .

- Fragments. Paris: Aubier Montaigne, 1973.

SCHLEGEL, Friedrich. Conversa sobre a poesia e outros fragmentos. Tradução de Victor-Pierre Stirnimann. São Paulo: Iluminuras, 1994.

- Obras selectas. Tradução de Miguel Angel Vega. Madrid: Fundación Universitaria Española, 1983. 